DOI: $10.30519 /$ ahtr.550600

Advances in Hospitality and Tourism Research (AHTR)

\title{
THE EFFECTS OF FOOD-RELATED MOTIVATION, LOCAL FOOD INVOLVEMENT, AND FOOD SATISFACTION ON DESTINATION LOYALTY: THE CASE OF ANGELES CITY, PHILIPPINES
}

\author{
Jean Paolo G. LACAP ${ }^{1}$ \\ City College of Angeles, Philippines \\ ORCID: 0000-0002-4152-9061
}

\begin{abstract}
The paper examines the effect of local food on loyalty of tourists on a destination. The participants were identified using purposive method of sampling and these respondents comprised of local and foreign tourists who have visited Angeles City. The research design used was predictive-correlational method and partial least squares path modelling was utilized to gauge the parameter estimates. The results showed that food-related motivation positively affects local food involvement, destination loyalty, and food satisfaction. It was also found out that local food involvement is significantly and positively related to food satisfaction and destination loyalty. Moreover, relationship between food satisfaction and destination loyalty was found to be significant and positive. The mediation analysis revealed that food satisfaction is a mediator on the link between food-related motivation and destination loyalty and between local food involvement and destination loyalty.
\end{abstract}

\author{
Article History \\ Received 8 April 2019 \\ Revised 2 December 2019 \\ Accepted 4 December 2019 \\ Keywords \\ local food \\ food-related motivation \\ local food involvement \\ food satisfaction \\ food tourism \\ destination loyalty
}

\section{INTRODUCTION}

Local food is an integral component in the field of tourism since it is considered a resource which can be utilized by destinations, locations, and countries in their marketing campaigns and events. Furthermore, it significantly creates an impact when it comes to destination branding and

\footnotetext{
${ }^{1}$ Address correspondence to Jean Paolo G. Lacap, Vice President for Administration and Quality Assurance, City College of Angeles, Angeles City, PHILIPPINES. Email: jpglacap@gmail.com
} 
even development of localities, cities, or regions. Since local food is part of culture, each destination of nation is represented by unique or exemplary dishes (Björk \& Kauppinen-Räisänen, 2016). With the increasing importance given to food as part of cultural tourism (Hall \& Mitchell, 2007; Hjalager \& Richards, 2003), local food has the capacity to attain tourism sustainability and at the same time, augment destination authenticity, foster stronger domestic economy, and contribute in establishing sustainable tourism infrastructure (Handszuh, 2000).

Food tourism or gastronomic tourism is gaining momentum and popularity. More and more tourists are motivated to travel because of activities and events related to food. Tourists seek these activities to experience iconic local delicacies or products and, at the same time, experience unique events (Kivela \& Crotts, 2006). The desire of tourists to experience authentic and unique food experience is now a budding occurrence in tourism industry (Smith \& Costello, 2009). When tourists enjoy local food, they acquire memorable travel experiences because local food is highly associated with local cultures and histories, which may evoke lasting memories (Tsai, 2016).

Pampanga is known to be the culinary capital of the Philippines. Angeles City, being one of the cities in Pampanga, is a haven for several cultural and historic landmarks. Aside from heritage treasures, Angeles City boasts itself as a culinary destination. The city is known for the world renowned "sisig," a local dish which is a pork hash made with pork face, ears, cheeks, and snout. And according to the late renowned chef, Anthony Bourdain, "sisig" could be the next big trend (Thomson, 2017). Because of the popularity of "sisig," Angeles City stages Sisig Fiesta annually to celebrate this local dish. The Sisig Fiesta is celebrated to preserve and commemorate the significance of "sisig" not only in Pampanga but in the entire Philippines. With the fame of "sisig," Angeles City is now bidding in the United Nations Educational, Scientific and Cultural Organization (UNESCO) Creative Cities Network, Gastronomy category (Magalog-De Veyra, 2018).

Several studies have identified the key role of local food or food in general in enhancing the value of a destination, may it be in local economy, culture, destination identity, and growth and sustainability. Hence, food as a tourism resource, is fundamentally getting more attention because of its contribution to tourism sustainability (Chen \& Huang, 2019; Everett \& Aitchison, 2008; Everett \& Slocum, 2013; Sims, 2009). Local food directly and indirectly influences sustainability in a 
destination (Du Rand \& Heath, 2006; Everett \& Slocum, 2013; Sims, 2009). It can expand tourism sustainability, may it be in the aspect of economic, social or environmental, through revenue generation, support for local establishments, and can provide tourists' needs for local tourism experience (Berno et al., 2014; Sims, 2009). Being a culinary destination, the main goal of the present study is to explore the food-related factors including food-related motivation, local food involvement, and food satisfaction that influence destination loyalty of tourists in Angeles City.

\section{RESEARCH FRAMEWORK AND HYPOTHESIS DEVELOPMENT}

\section{Destination Loyalty}

In marketing, loyalty from the customers is an important measure of a firm's success. Loyalty to a specific product or service extends in various studies in the field of hospitality and tourism, in particular, destination loyalty (Suhartanto et al., 2018). Examining destination loyalty can be done through analysis of one's behavior or attitude (Hapsari et al., 2017). The behavioral approach to destination loyalty entails purchase of a tourism product or service or a repeated manner. On the other hand, the attitudinal approach entails the relative strength of tourist's affection towards a tourism product or service (Mechinda et al., 2009; Prayag \& Ryan, 2012). The present study utilized the attitudinal dimension of destination loyalty as it is used in many research studies (e.g. Di-Clemente et al., 2019; Kim et al., 2015; Lin, 2014; Loureiro, 2014; Mechinda et al., 2009).

\section{Food-related Motivation}

There are many reasons why a tourist visits a place or a destination. Fundamentally, tourists travel or visit a destination because of a motivation (Ngwira \& Kankhuni, 2018). It is the beginning of any travelrelated activities (Nikjoo \& Ketabi, 2015). It is the individual's drive to address a need and to obtain value in their lives (Oliver, 2014). So, when a tourist travels or visits a destination, he or she is confronted with numerous travel motives and these factors include food-related motivations (Kim et al., 2013; Kim \& Eves, 2012; Kivela \& Crotts, 2009). Consumption of food has been one of the many activities of tourists and food as a travel motive may affect the choices of tourists when it comes to food (Ji et al., 2016). Hence, food is an important travel motive for tourists 
and can also be treated as a secondary motivator for some travelers (Hall et al., 2004). From these related studies, food-related motivations are tourists' travel motives related to destination's local food.

Local food is an integral component of a lasting tourism experience and a tool for tourists to understand a tourist destination. With the proliferation of travel shows, magazines, and the like, tourists are much exposed to various motivators including local food of a destination which may heighten their interest for local dishes and stimulate their motivation to experience local cuisines (Tsai, 2016). Levitt et al. (2017) found out that tourists with high motivation and involvement in food in a destination have the greatest intentions to consume local food and they exhibit highest favorable attitudes towards local dishes. Furthermore, the factors that tourists consider in attaining food satisfaction are their desires and expectations based on their previous food experiences (Andersen \& Hyldig, 2015). On the other hand, Chen and Huang (2019) observed that food-related motivation of Chinese tourists was found to be an insignificant factor to destination loyalty. In the study of Agyeiwaah et al. (2019), the authors revealed that the motivation of tourists is directly related to culinary satisfaction and experience. They further indicated that higher motivation of tourists leads to participation and involvement in the culinary experience, thus increasing their level of satisfaction, and in the long run, their loyalty. Therefore, it is hypothesized that:

H1a. Food-related motivation positively affects local food involvement.

H1b. Food-related motivation positively affects destination loyalty.

H1c. Food-related motivation positively affects food satisfaction.

\section{Local Food Involvement}

The concept of involvement in the field of tourism has been used to evaluate the level of satisfaction of tourists (Green \& Chalip, 1998; Laverie \& Arnett, 2000). According to Sherif and Sherif (1967), involvement is a form of attitude and it happens when one interacts with the social environment. Moreover, Laurent and Kapferer (1985) argued that involvement is influenced by satisfaction and loyalty, in varying degrees. Based on these related studies and literature, local food involvement refers to the degree in which a tourist involve himself or herself in food-related activities of a destination. In the study of Chen and Huang (2019), the authors found out that local food involvement among tourists in China is nothing to do with destination loyalty. Contrary, in the research study of Prayag and Ryan (2012), involvement of tourists is a predictor of loyalty 
where satisfaction is a mediator. Moreover, Lee and Chang (2012) found out that tourist involvement positively affects loyalty, mediated by satisfaction. Hence, it is postulated that:

H2a. Local food involvement positively affects food satisfaction.

$\mathrm{H} 2 \mathrm{~b}$. Local food involvement positively affects destination loyalty.

\section{Food Satisfaction}

Satisfaction of tourists is both cognitive and affective and it is based on tourism experience in a destination (Rodriguez \& San Martin, 2008). In the present study, food satisfaction is basically the favorable response of a tourist to his or her tourism experience in a food destination. It has a behavioral component which can lead to loyalty to a destination (San Martín et al., 2018). In the study of Chen and Chen (2010), tourist satisfaction is positively correlated with destination loyalty. On the other hand, destination loyalty, based on the present study, refers to the degree to which forms an intention to revisit a particular destination (Meleddu et al., 2015). In the study of Chen and Huang (2019), the authors observed that food satisfaction among tourists in China was directly related to destination loyalty. Thus, it is predicted that:

H3. Food satisfaction positively affects destination loyalty.

Examination of previous studies show that there are limited research undertakings on the mediating effects of food satisfaction on different tourism constructs. Namkung and Jang (2007) examined how food quality affects customer satisfaction and behavioral intentions. The findings showed that customer satisfaction acts as mediator between food quality and behavioral intentions. Moreover, Chen and Huang (2019) found that food satisfaction partially mediates local-food involvement and destination loyalty. Therefore, it is hypothesized that:

H4. Food satisfaction mediates the direct link of food-related motivation and destination loyalty.

H5. Food satisfaction mediates the direct link of local food involvement and destination loyalty.

Based on the research hypotheses formulated, a model of destination loyalty was conceptualized (see Figure 1). The proposed model assesses the influence of food-related motivation, local food involvement, and food satisfaction on loyalty to a destination. Aside from the investigation of the direct effects, the current study also examines the 
mediating role of food satisfaction on the relationship between foodrelated motivation and destination loyalty, and on the link between local food involvement and destination loyalty.

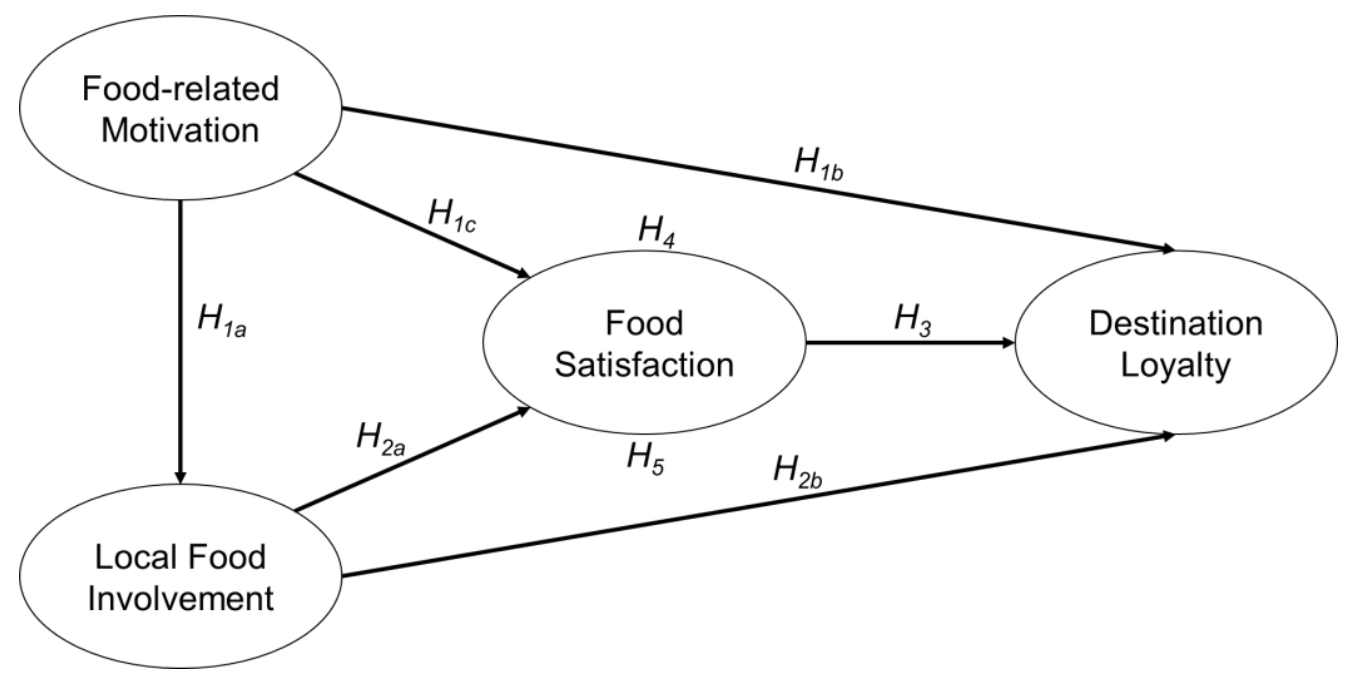

Figure 1. Proposed model of destination loyalty

\section{METHOD}

\section{Participants of the Study}

The respondents of the study were local and foreign tourists who have travelled or visited Angeles City. The sampling method used was purposive. Out of 500 survey questionnaires distributed, 352 were completed accurately by the respondents, resulting in a response rate of $70.4 \%$. The survey questionnaires were floated in August 2018 and ended in October 2018.

The gathering of data through survey was conducted face-to-face. The enumerators were stationed in various landmarks and tourist spots of Angeles City. Each respondent of legal age (18 years old and above) was asked whether he or she has stayed overnight in the city for him or her to be qualified as a respondent. Those who have stayed overnight were considered as the participants of the study.

The socio-demographic profile of the participants is reflected in Table 1. Eighty-five percent of the total respondents were local tourists. Out of 352, 86\% were Filipino nationals. There was an almost equal distribution in terms of sex, and out of the total participants, $40 \%$ were 
employed while 39\% were college students. In terms of purpose of visit, $36 \%$ travelled to Angeles City to visit a friend / family while 36\% responded for leisure.

Table 1. Sample's Socio-Demographic Profile

\begin{tabular}{lrr}
\hline Respondents' Characteristics & Frequency & Percent \\
\hline Type of Tourist & & \\
Local & 299 & 84.9 \\
$\quad$ Foreign & 53 & 15.1 \\
\hline Nationality & & \\
$\quad$ Filipino & 303 & 86.1 \\
$\quad$ Non-Filipino & 49 & 13.9 \\
\hline Sex & & \\
Male & 169 & 48.0 \\
Female & 183 & 52.0 \\
\hline Occupation & & \\
College Student & 136 & 38.6 \\
Employed & 142 & 40.3 \\
Self-Employed & 34 & 9.7 \\
$\quad$ Unemployed & 40 & 11.4 \\
\hline Purpose of Visit & & \\
Leisure & 125 & 35.5 \\
Meeting or event & 24 & 6.8 \\
Visiting friends/family & 127 & 36.1 \\
Business trip & 29 & 8.2 \\
Others & 47 & 13.4 \\
\hline
\end{tabular}

\section{Sufficiency of the Sample}

The present study has a total of 352 respondents. In order to measure whether the sample size is robust enough to support the results of the proposed structural model, inverse-square root and Gamma-exponential methods (Kock \& Hadaya, 2018) were applied. Looking at the PLS path model in Figure 3, the minimum significant path coefficient is 0.16 . Moreover, with the level of significant of 0.05 and power level of 0.80 , using the statistical software WarpPLS version 6.0 (Kock, 2017), the computed sample sizes were the following 242 (using inverse-square root) and 228 (using Gamma-exponential) as reflected in Figure 2. Therefore, 352 as the sample size signifies that the robustness of the proposed model. 

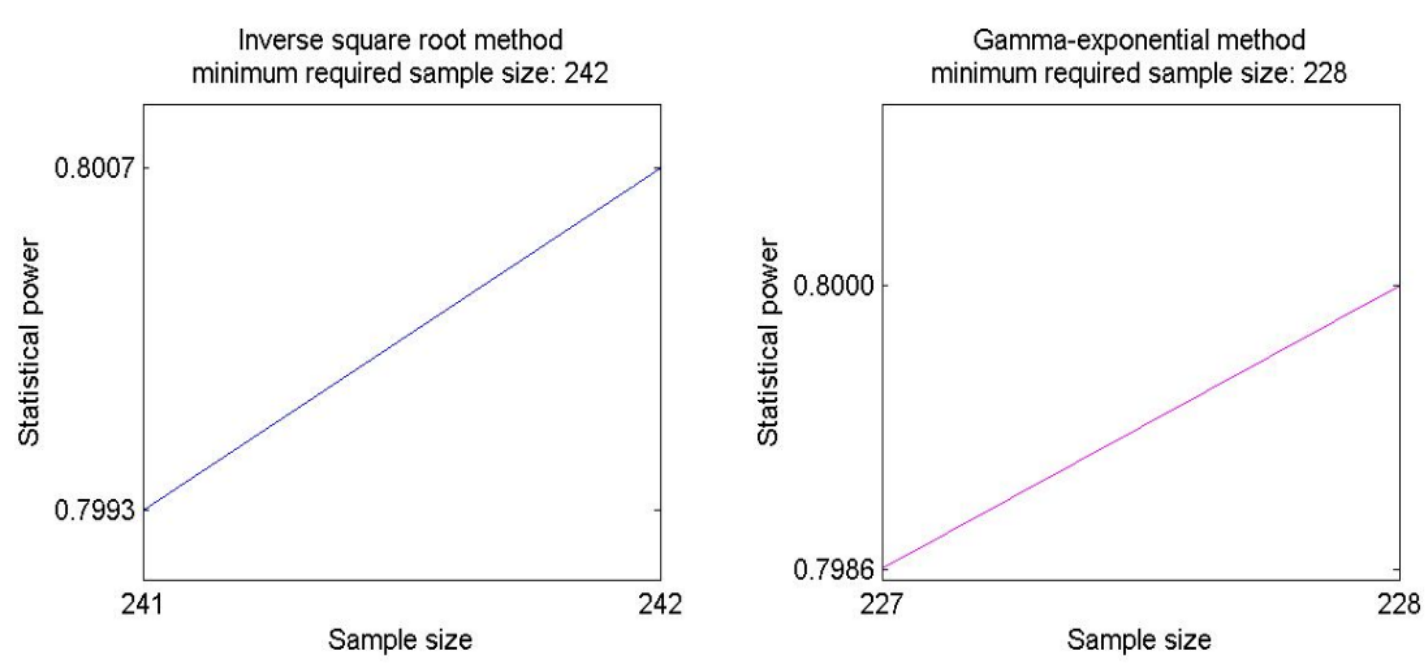

Figure 2. Sample size estimates

\section{Research Instrument}

The current undertaking utilized a questionnaire as the research instrument. The instrument contained the demographics of the respondents - type of tourist, nationality, sex, occupation, and purpose of visit - and the items (measured using 5-point Likert scale) for the four (4) latent variables - food-related motivation, local food involvement, food satisfaction, and destination loyalty.

The six (6) items for food-related motivation were based on the studies of Beer et al. (2012), McKercher et al. (2008), and Kim et al. (2010) which were summarized, validated, and tested for reliability in the study of Chen and Huang (2019). The present study adapted these items and were quantified employing a 5-point Likert scale (level of agreement/disagreement).

On the other hand, the 8 items for local food involvement were adopted from the study of Sparks (2007) which are modified version of the Personal Involvement Inventory scale (Zaichkowsky, 1985). The items were also measured using 5-point Likert scale (level of agreement/disagreement).

As for the 5 items for food satisfaction, these items were based on several studies including Bosque and Martin (2008), Mason and Paggiaro (2012), Zabkar et al. (2010) which were summarized, validated, and tested for reliability also in the study of Chen and Huang (2019). The present 
study adapted these items and were measured using a 5-point Likert scale (level of agreement/disagreement).

Finally, the 3 items for destination loyalty came from the study of Zabkar et al. (2010). All the items for the 4 latent variables were refined in the research undertaking of Chen and Huang (2019).

\section{Data Analysis}

To test the applicability of the proposed structural model on the role of food on destination loyalty, a predictive-correlational design was utilized. A partial least squares - structural equation modelling (PLS-SEM) was used to measure the parameter estimates of the proposed model. The PLSSEM is a statistical test that follows three (3) stages: specification of the model, evaluation of the outer model, and assessment of the inner model. The present study also employed mediation analysis to gauge how mediators absorb the effect of the exogenous (independent) variable on an endogenous (dependent) construct in a structural model (Hair et al., 2014).

\section{RESULTS}

\section{Model Fit and Quality Indices}

Table 2 presents the 10 global model fit quality indices. The model fit and quality indices evaluates model quality of the proposed framework (Kock, 2017).

According to Kock (2011), the evaluation of the fit of the structural model, $\mathrm{p}$-values of APC, ARS, and AARS must be significant ( $\mathrm{p}<0.05$ ). Moreover, the coefficients of AVIF and AFVIF must be equal to or less than 3.3 (Kock \& Lynn, 2012). As seen in Table 2, the mentioned indices are within the accepted ranges.

With regard to Tenenhaus GoF, a measure of explanatory power of the structural model (Tenenhaus et al., 2005), the coefficient corresponds to the following thresholds: small if GoF is greater than or equal to 0.1, medium if GoF is greater than or equal to 0.25 , and large if GoF is greater than or equal to 0.36 (Wetzels et al., 2009). With Tenenhaus GoF $=0.510$, this indicates that the goodness of fit of the model is large, therefore, the model is highly acceptable. 
Table 2. Model fit and quality indices

\begin{tabular}{lc}
\hline Model Fit and Quality Indices & Coefficients \\
\hline Average path coefficient (APC) & $0.336, p<0.001$ \\
Average R-squared (ARS) & $0.378, p<0.001$ \\
Average adjusted R-squared (AARS) & $0.375, p<0.001$ \\
Average block variance inflation (AVIF) & 1.622 \\
Average full collinearity VIF (AFVIF) & 1.767 \\
Tenenhaus GoF & 0.510 \\
Simpson's paradox ratio (SSR) & 1.000 \\
R-squared contribution ratio (RSCR) & 1.000 \\
Statistical suppression ratio (SSR) & 1.000 \\
Non-linear bivariate causality direction & 1.000 \\
ratio (NLBCDR) & \\
\hline
\end{tabular}

In terms of SPR, a measure of the possible causality problem in a structural model (Kock, 2017), and RSCR, an index that gauges the degree to which the structural model has no negative R-squared contributions (Kock, 2015; Kock \& Gaskins, 2016; Pearl, 2009; Wagner, 1982), the thresholds are as follows: SPR and RSCR must be equal to 1 or a more relaxed criterion, they must be equal to or higher than 0.7 (Kock, 2017). With SPR and RSCR having values equal to 1, the results suggest Simpson's paradox is not present and there are no negative R-squared contributions in the structural model.

And, as for the coefficients of SSR and NLBCDR, the acceptable values must be equal to or greater than 0.7 . The SSR is an index that gauges whether the structural model does not have or does not encounter suppression instances. On the other hand, NLBCR measures how bivariate non-linear values support the hypothesized directions of causal relationships of a structural model (Kock, 2017). With SSR and NLBCDR having values equal to 1 , the results indicate that the structural paths are free from statistical suppression and the causality of the hypothesized path direction of the model is supported.

\section{Collinearity, Reliability, and Validity Measurements}

The block variance inflation factors (VIFs) measure whether multicollinearity exists or not (Lacap et al., 2018). According to Kock \& Lynn (2012), the threshold for block VIFs must be equal to or lower than 3.3. As seen in Table 3, all VIFs are below 3.3 suggesting that there is no vertical multicollinearity in all latent constructs in the structural model. 
To gauge the reliability of each construct, composite reliability (CR) and Cronbach's alpha (CA) were measured. The values of CR and CA must be at least 0.70 (Fornell \& Larcker, 1981; Nunnally, 1978; Nunnally \& Bernstein, 1994; Kock, 2017; Kock \& Lynn, 2012). With the coefficients of CR and CA for each variable, as shown in Table 3, all constructs are highly reliable.

Table 3. Collinearity, convergent validity, and reliability measures

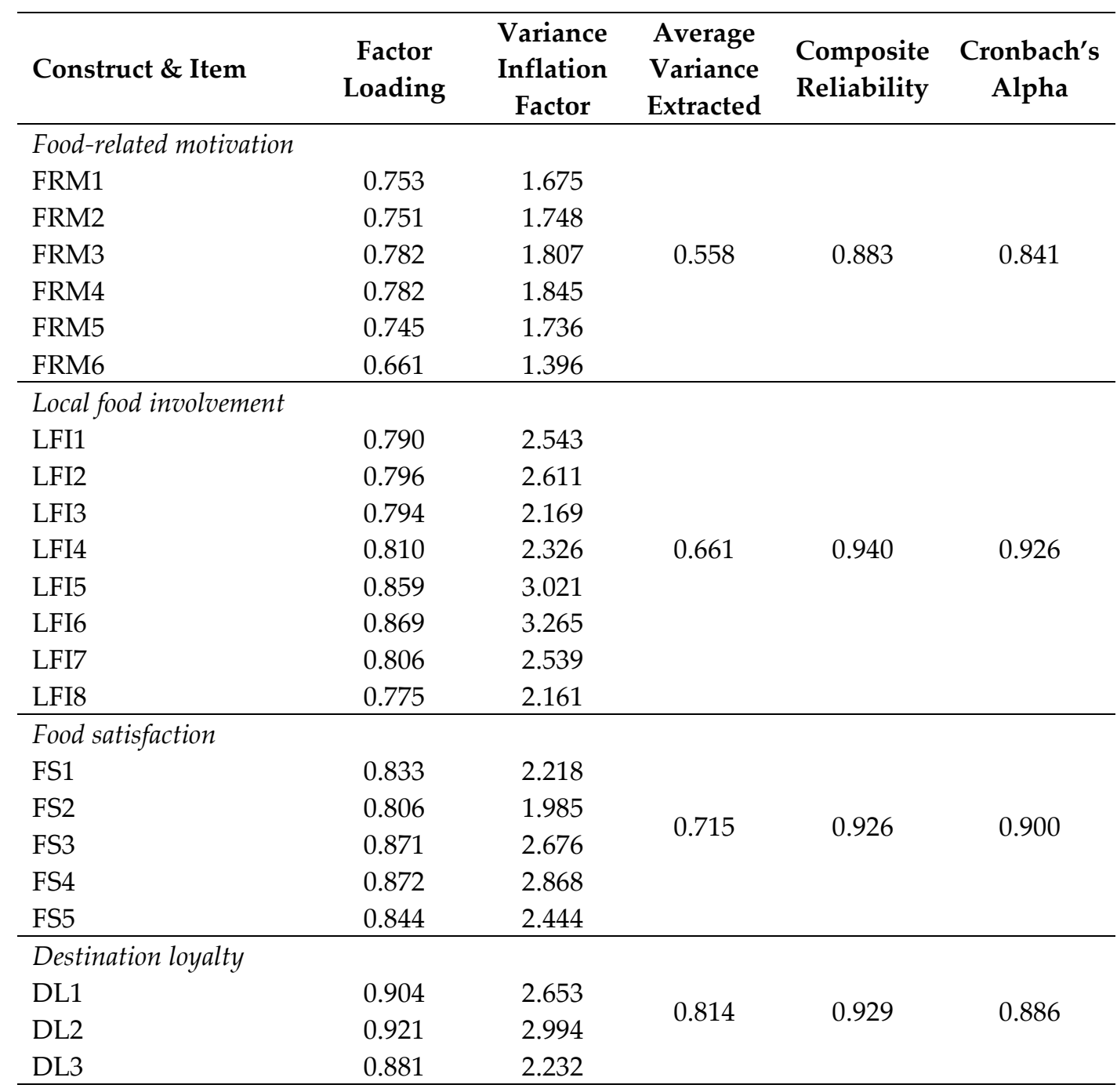

All factor loadings are significant at $0.001(p<0.001)$.

Convergent and discriminant validity tests were also measured. A construct is said to have a convergent validity when the factor loading of each item at least 0.5 or higher at the corresponding p-value must be significant, $\mathrm{p}<0.05$. (Hair et al., 2009; Kock, 2014). Furthermore, discriminant validity involves the evaluation of average variance extracted 
(AVEs). The values of AVEs must be at least 0.5 or higher (Fornell \& Larcker, 1981; Kock \& Lynn, 2012). At the same time, discriminant validity also involves the scrutiny of the correlations among constructs with square roots of AVEs (Kock, 2017; Lacap, 2019). The diagonal values (see Table 4), must be larger than the values to their left in the same row (Kock, 2017). As shown in Tables 3 and 4, all constructs exhibit convergent and discriminant validity.

Table 4. Discriminant validity using Fornell and Larcker criterion

\begin{tabular}{lcccc}
\hline & FRM & LFI & FS & DL \\
\hline FRM & $\mathbf{0 . 7 4 7}$ & & & \\
LFI & 0.596 & $\mathbf{0 . 8 1 3}$ & $\mathbf{0 . 8 4 5}$ & $\mathbf{0 . 9 0 2}$ \\
FS & 0.463 & 0.524 & 0.615 & \\
DL & 0.461 & 0.496 & local food involvement; FS = food satisfaction; $D L=$ \\
\hline FRM = food-related motivation; & LFI = lof \\
destination loyalty. The diagonal values are the square root of $A V E$ of constructs while the off- \\
diagonal elements are the correlation between constructs.
\end{tabular}

\section{PLS-Path Model}

Figure 3 and Table 5 display the PLS path model and the direct effects of each structural path. Analysis of data revealed that food-related motivation positively affects local food involvement $(\beta=0.614, p<0.001)$, destination loyalty $(\beta=0.158, p=0.001)$, and food satisfaction $(\beta=0.238, p<$ 0.001). The effect sizes for FRM $\rightarrow$ LFI is medium $\left(f^{2}=0.337\right)$, FRM $\rightarrow$ DL is small $\left(f^{2}=0.074\right)$, and for FRM $\rightarrow$ FS is small $\left(f^{2}=0.113\right)$. Therefore, H1a, $\mathrm{H} 1 \mathrm{~b}$, and H1c are supported.

Moreover, local food involvement showed positive influence on food satisfaction $(\beta=0.386, p<0.001)$ and on destination loyalty $(\beta=0.160$, $p=0.001)$. The relationship between LFI and FS has a medium effect size $\left(f^{2}\right.$ $=0.205)$ while the relationship between LFI and DL has a small effect size $\left(f^{2}=0.079\right)$. Hence, $\mathrm{H} 2 \mathrm{a}$ and $\mathrm{H} 2 \mathrm{~b}$ are supported. Additionally, results also revealed that food satisfaction positively affects destination loyalty ( $\beta=$ $0.463, p<0.001)$ with an effect size of medium $\left(f^{2}=0.287\right)$. Thus, H3 is supported. 


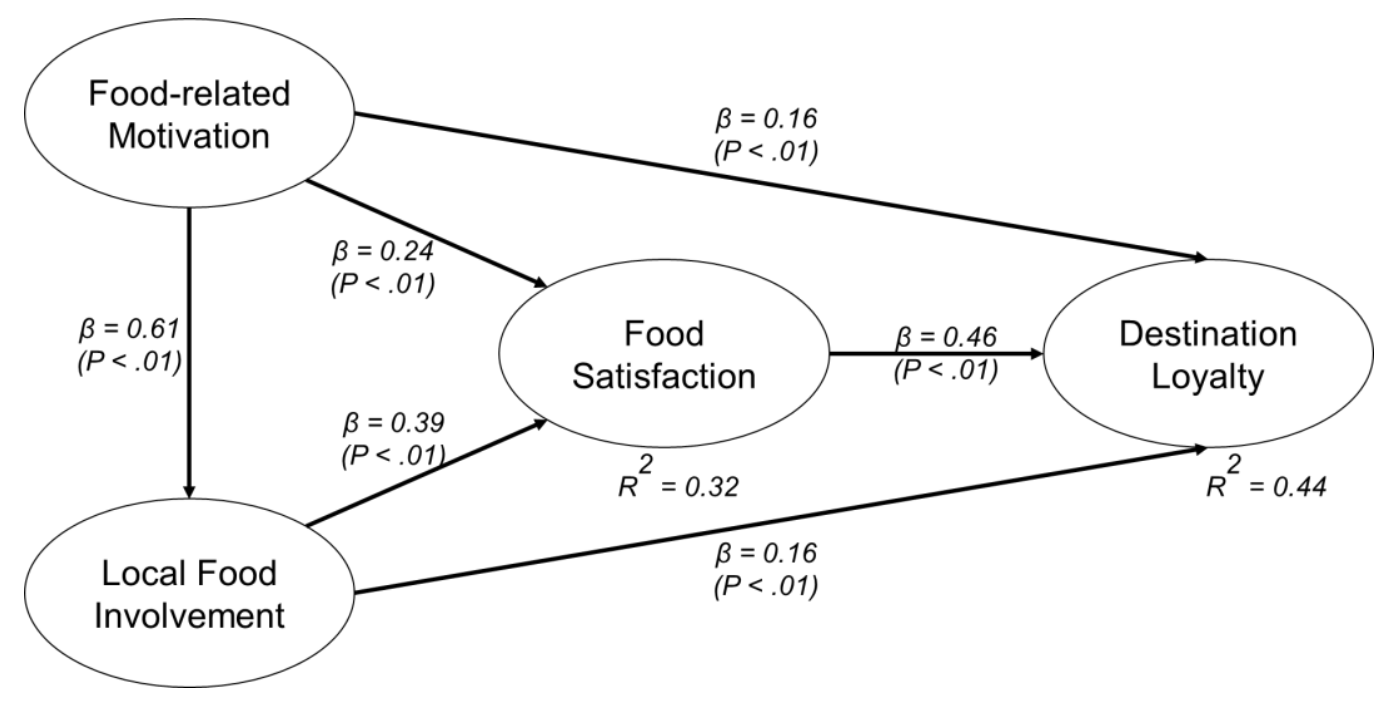

Figure 3. The PLS path model with parameter estimates

Table 5 also manifests the mediation effects results for $\mathrm{H} 4$ and $\mathrm{H} 5$. The findings showed that food satisfaction partially mediates the direct link between food-related motivation and destination loyalty $(\beta=0.110, p=$ 0.002) with a small effect size $\left(f^{2}=0.052\right)$ and between local food involvement and destination loyalty $(\beta=0.179, p<0.001)$, with a small effect size $\left(f^{2}=0.089\right)$. Hence, H4 and H5 are supported.

Table 5. Direct and indirect effects

\begin{tabular}{|c|c|c|c|c|}
\hline & $\begin{array}{c}\text { Path } \\
\text { Coefficient }\end{array}$ & Standard Error & $p$-value & Effect Size \\
\hline \multicolumn{5}{|l|}{ Direct Effects } \\
\hline H1a. FRM $\rightarrow$ LFI & 0.614 & 0.049 & $<0.001$ & 0.337 \\
\hline H1b. FRM $\rightarrow$ DL & 0.158 & 0.052 & 0.001 & 0.074 \\
\hline H1c. FRM $\rightarrow$ FS & 0.238 & 0.051 & $<0.001$ & 0.113 \\
\hline H2a. LFI $\rightarrow$ FS & 0.386 & 0.050 & $<0.001$ & 0.205 \\
\hline $\mathrm{H} 2 b . \mathrm{LFI} \rightarrow \mathrm{DL}$ & 0.160 & 0.052 & 0.001 & 0.079 \\
\hline H3. FS $\rightarrow$ DL & 0.463 & 0.050 & $<0.001$ & 0.287 \\
\hline \multicolumn{5}{|l|}{ Indirect Effects } \\
\hline H4. FRM $\rightarrow$ FS $\rightarrow$ DL & 0.110 & 0.037 & 0.002 & 0.052 \\
\hline H5. LFI $\rightarrow$ FS $\rightarrow$ DL & 0.179 & 0.037 & $<0.001$ & 0.089 \\
\hline
\end{tabular}


The coefficient of determination or the R-squared $\left(R^{2}\right)$ values were also shown in Figure 3. Based on the structural model, the R2 coefficients of 0.32 and 0.44 or an ARS of 0.378 indicate that about $38 \%$ of the variability of dependent construct/s can be explained by the independent construct/s $(\mathrm{p}<0.001)$.

\section{DISCUSSION}

The current research revealed that food-related motivation positively affects local food involvement, destination loyalty, and food satisfaction. The findings suggest that, when the travel motives of tourists are related to local food and these motives can be found in a destination, they will involve themselves in food-related activities of that destination and the same time, they will have positive attitudes towards the destination and may result in revisit intention. These results are in consonance with the study of Levitt et al. (2017) who argued that when motivation and degree of involvement of tourists is high, their propensity to consume local food rises, and at the same time, they exhibit favorable attitudes towards local cuisine. Same also is true with the study of Andersen and Hyldig (2015) who identified that previous food experiences contribute to food satisfaction of tourists. Moreover, Agyeiwaah et al. (2019) highlighted that when tourists are motivated by food, their culinary experience becomes favorable and their culinary satisfaction increases which leads them to become involved in their food experiences. Contrary, Chen and Huang (2019) found that food-related motivation does not contribute to destination loyalty of tourists.

Furthermore, analysis of the data also revealed that local food involvement positively affects food satisfaction and destination loyalty. This indicates that, when tourists visit a destination and they immerse themselves in activities related to local food, the propensity of a satisfactory experience and revisit the same destination is high. This is true with the studies of Laurent and Kapferer (1985), Prayag and Ryan (2012) and Lee and Chang (2012) who identified that when tourists are very much involved in a destination, it positively affects their degree of satisfaction and loyalty. On the other hand, Chen and Huang (2019) observed that local food involvement does not affect loyalty to a destination. Additionally, the study also revealed that food satisfaction directly affects destination loyalty. The favorable response of tourists to their food experiences forms revisit intentions to a destination. This is 
supported by the research studies of Chen and Chen (2010), Meleddu et al. (2015), and Chen and Huang (2019).

The mediation analysis showed that food satisfaction acts as a mediator on the relationship between food-related motivation and destination loyalty and local food involvement and destination loyalty. This suggests that food-related motivation and local food involvement positively affect food satisfaction which in turn affects destination loyalty. With a small effect size, food satisfaction augments the relationship between food-related motivation and destination loyalty and between local food involvement and destination loyalty. In the study of Chen and Huang (2019), the authors observed the partial mediation effects of food satisfaction on local food involvement and destination loyalty relationship and of local food involvement on food-related motivation and destination loyalty.

\section{Implications of the Study, Future Research Directions, and Limitations of the Study}

With the growing interests in food tourism or gastronomic tourism and the important role of local food in destination's value (Chen \& Huang, 2019; Everett \& Aitchison, 2008; Everett \& Slocum, 2013; Sims, 2009), the study provides a deeper understanding on the effects of food-related motivation, local food involvement, and food satisfaction on destination loyalty. Angeles City, being a food destination, offers local dishes and cuisines which can be an integral component of the strategic tourism marketing campaign for the city. Based on the results, all identified factors - of food-related motivation, local food involvement, and food satisfaction contribute to loyalty of tourists in a destination. These results prove that tourists, local and foreign, may form revisit intentions in Angeles City when they experience local food, involve themselves in food-related activities of the destination, and they have favorable experiences.

Local tourism officers and private food establishments must work together and create a holistic approach to emphasize local food as the banner tourism program of Angeles City. With food-related motivation positively affecting food satisfaction and, in turn, destination loyalty, sustainability of the destination is a possibility. Marketing efforts should be geared towards establishing Angeles City as a local food destination. Moreover, tourists should also experience being involved in food-related activities of a destination. Their level of involvement leads to food 
satisfaction. This factor also reinforces the food-motivation of the tourists which positively affects their level of food satisfaction. Presenting the local food and its vital relevance to the destination's culture and history and creating food-related activities regarding local dishes will generate positive experience among tourists of Angeles City.

Every destination desires to achieve sustainability and the present study emphasize the role of local food on destination loyalty. In order to attain sustainability in a food destination, food-related motivation, local food involvement, and food satisfaction should always be considered. With this, the research undertaking has also limitations. First, most of the respondents were local tourists and college students, hence future researchers may want to examine the present research model by including more foreign tourists and employed respondents in order to increase the generalizability of the conclusions. And second, it considers only the role of food in destination loyalty. Other researchers may look into other factors that may contribute to loyalty of tourists in destinations. Moreover, others may find interest in exploring further other food-related factors that may influence destination loyalty.

\section{REFERENCES}

Agyeiwaah, E., Otoo, F. E., Suntikul, W., \& Huang, W. J. (2019). Understanding culinary tourist motivation, experience, satisfaction, and loyalty using a structural approach. Journal of Travel \& Tourism Marketing, 36(3), 295-313. https://doi.org/10.1080/10548408.2018.1541775

Andersen, B. V., \& Hyldig, G. (2015). Consumers' view on determinants to food satisfaction. A qualitative approach. Appetite, 95, 9-16. https://doi.org/10.1016/j.appet.2015.06.011

Beer, C. L., Ottenbacher, M. C., \& Harrington, R. J. (2012). Food tourism implementation in the Black Forest destination. Journal of Culinary Science and Technology, 10(2), 106-128. https://doi.org/10.1080/15428052.2012.677601

Berno, T., Kline, C., \& Wolf, E. (2014). Food tourism in academia. In E. Wolf, J. Bussell, C. Campbell, W. Lange-Faria, \& K.McAree (Eds.), Have fork will travel: A practical handbook for food and drink tourism professionals (pp. 309-321). Portland: World Food Travel Association.

Björk, P., \& Kauppinen-Räisänen, H. (2016). Local food: A source for destination attraction. International Journal of Contemporary Hospitality Management, 28(1), 177194. https://doi.org/10.1108/IJCHM-05-2014-0214

Bosque, I. R. D., \& Martin, H. S. (2008). Tourist satisfaction a cognitive-affective model. Annals of Tourism Research, 35(2), 551-573. https://doi.org/10.1016/j.annals.2008.02.006

Chen, C. F., \& Chen, F. S. (2010). Experience quality, perceived value, satisfaction and behavioral intentions for heritage tourists. Tourism Management, 31(1), 29-35. https://doi.org/10.1016/j.tourman.2009.02.008 
Chen, Q., \& Huang, R. (2019). Understanding the role of local food in sustaining Chinese destinations. Current Issues in Tourism, 22(5), 544-560. https://doi.org/10.1080/13683500.2018.1444020

Cohen, J. (1988). Statistical power analysis for the behavioral sciences. Hilsdale NJ: Lawrence Earlbaum.

Di-Clemente, E., Hernández-Mogollón, J. M., \& Campón-Cerro, A. M. (2019). Food-based experiences as antecedents of destination loyalty. British Food Journal, 121(7), 1495-1507. https://doi.org/10.1108/BFJ-07-2018-0419

Du Rand, G. E., \& Heath, E. (2006). Towards a framework for food tourism as element of destination marketing. Current Issues in Tourism, 9(3), 206-234. https://doi.org/10.2164/cit/226.0

Everett, S., \& Aitchison, C. (2008). The role of food tourism in sustaining regional identity: A case study of Cornwall, South West England. Journal of Sustainable Tourism, 16(2), 150-167. https://doi.org/10.2167/jost696.0

Everett, S., \& Slocum, S. L. (2013). Food and tourism: An effective partnership? A UKbased review. Journal of Sustainable Tourism, 21(6), 789-809. https://doi.org/10.1080/09669582.2012.741601

Fornell, C., \& Larcker, D. F. (1981). Evaluating structural equation models with unobserved variables and measurement error. Journal of Marketing Research, 18(1), 39-50. http://doi.org/10.2307/3151312

Green, B. C., \& Chalip, L. (1998). Antecedents and consequences of parental purchase decision involvement in youth sport. Leisure Sciences, 20(2), 95-109. https://doi.org/10.1080/01490409809512268

Hair, J. F., Black, W. C., Babin, B. J., \& Anderson, R. E. (2009). Multivariate Data Analysis. Upper Saddle, NJ: Pearson.

Hair, J.F., Sarstedt, M., Hopkins, L., \& Kuppelwieser, V. G. (2014). Partial least squares structural equation modeling (PLS-SEM) An emerging tool in business research. European Business Review, 26(2), 106-121. https://doi.org/10.1108/EBR-10-2013-0128

Hall, C. M., \& Mitchell, R. (2007). Gastronomic tourism: Comparing food and wine tourism experiences. In M. Novelli (Ed.), Niche tourism (pp. 87-102). Routledge.

Hall, C. M., Sharples, L., \& Smith, A. (2004). The experience of consumption or the consumption of experiences? Challenges and issues in food tourism. In C. M. Hall, L. Sharples, R. Mitchell, N. Macionis, \& B. Cambourne (Eds.), Food tourism around the world (pp. 314-335). Routledge.

Handszuh, H. F. (2000). Local food in tourism policies. In WTO-CTO local food \& tourism international conference, Larnaka, Cyprus, 9-11 November 2000 (pp. 173-179). World Tourism Organization (WTO).

Hapsari, R., Clemes, M. D., \& Dean, D. (2017). The impact of service quality, customer engagement and selected marketing constructs on airline passenger loyalty. International Journal of Quality and Service Sciences, 9(1), 21-40. https://doi.org/10.1108/IJQSS-07-2016-0048

Hjalager, A. M., \& Richards, G. (Eds.). (2003). Tourism and gastronomy. Routledge.

Ji, M., Wong, I. A., Eves, A., \& Scarles, C. (2016). Food-related personality traits and the moderating role of novelty-seeking in food satisfaction and travel outcomes. Tourism Management, 57, 387-396. https://doi.org/10.1016/j.tourman.2016.06.003

Kim, H., Woo, E., \& Uysal, M. (2015). Tourism experience and quality of life among elderly tourists. Tourism management, 46, 465-476. https://doi.org/10.1016/j.tourman.2014.08.002 
Kim, Y. G., \& Eves, A. (2012). Construction and validation of a scale to measure tourist motivation to consume local food. Tourism management, 33(6), 1458-1467. https://doi.org/10.1016/j.tourman.2016.06.003

Kim, Y. G., Eves, A., \& Scarles, C. (2013). Empirical verification of a conceptual model of local food consumption at a tourist destination. International Journal of Hospitality Management, 33, 484-489. https://doi.org/10.1016/j.ijhm.2012.06.005

Kim, Y. G., Suh, B. W., \& Eves, A. (2010). The relationships between food-related personality traits, satisfaction, and loyalty among visitors attending food events and festivals. International Journal of Hospitality Management, 29(2), 216-226. https://doi.org/10.1016/j.ijhm.2009.10.015

Kivela, J., \& Crotts, J. C. (2006). Tourism and gastronomy: Gastronomy's influence on how tourists experience a destination. Journal of Hospitality $\mathcal{E}$ Tourism Research, 30(3), 354-377. https://doi.org/10.1177/1096348006286797

Kivela, J. J., \& Crotts, J. C. (2009). Understanding travelers' experiences of gastronomy through etymology and narration. Journal of Hospitality \& Tourism Research, 33(2), 161-192. https://doi.org/10.1177/1096348008329868

Kock, N. (2011). Using WarpPLS in e-collaboration studies: Descriptive statistics, settings, and key analysis results. International Journal of e-Collaboration (IJeC), 7(2), 1-18. https://doi.org/10.4018/jec.2011040101

Kock, N. (2014). Advanced mediating effects tests, multi-group analyses, and measurement model assessments in PLS-based SEM. International Journal of eCollaboration (IJeC), 10(1), 1-13. https://doi.org/10.4018/ijec.2014010101

Kock, N. (2015). How Likely is Simpson's Paradox in Path Models? International Journal of e-Collaboration (IJeC), 11(1), 1-7. https://doi.org/10.4018/ijec.2015010101

Kock, N. (2017). WarpPLS 6.0 user manual. Laredo, TX: ScriptWarp Systems.

Kock, N., \& Gaskins, L. (2016). Simpson's paradox, moderation, and the emergence of quadratic relationships in path models: An information systems illustration. International Journal of Applied Nonlinear Science, 2(3), 200-234. https://doi.org/10.1504/IJANS.2016.077025

Kock, N., \& Hadaya, P. (2018). Minimum sample size estimation in PLS-SEM: The inverse square root and gamma-exponential methods. Information Systems Journal, 28(1), 227-261. http://doi.org/10.1111/isj.12131

Kock, N., \& Lynn, G. (2012). Lateral collinearity and misleading results in variance-based SEM: An illustration and recommendations. Journal of the Association for Information Systems, 13(7), 546-580.

Lacap, J. P. G. (2019). The mediating effect of employee engagement on the relationship of transformational leadership and intention to quit: Evidence from local colleges in Pampanga, Philippines. Asia-Pacific Social Science Review, 19(1) 2019, 33-48.

Lacap, J. P. G., Mulyaningsih, H. D., \& Ramadani, V. (2018). The mediating effects of social entrepreneurial antecedents on the relationship between prior experience and social entrepreneurial intent: The case of Filipino and Indonesian university students. Journal of Science and Technology Policy Management, 9(3), 329-346. https://doi.org/10.1108/JSTPM-03-2018-0028

Laurent, G., \& Kapferer, J. N. (1985). Measuring consumer involvement profiles. Journal of marketing research, 22(1), 41-53. https://doi.org/10.1177/002224378502200104

Laverie, D. A., \& Arnett, D. B. (2000). Factors affecting fan attendance: The influence of identity salience and satisfaction. Journal of Leisure Research, 32(2), 225-246. https://doi.org/10.1080/00222216.2000.11949915 
Lee, T. H., \& Chang, Y. S. (2012). The influence of experiential marketing and activity involvement on the loyalty intentions of wine tourists in Taiwan. Leisure Studies, 31(1), 103-121. https://doi.org/10.1080/02614367.2011.568067

Levitt, J. A., Zhang, P., DiPietro, R. B., \& Meng, F. (2017). Food tourist segmentation: Attitude, behavioral intentions and travel planning behavior based on food involvement and motivation. International Journal of Hospitality $\mathcal{E}$ Tourism Administration, 1-27. https://doi.org/10.1080/15256480.2017.1359731

Lin, C. H. (2014). Effects of cuisine experience, psychological well-being, and self-health perception on the revisit intention of hot springs tourists. Journal of Hospitality $\mathcal{E}$ Tourism Research, 38(2), 243-265. https://doi.org/10.1177/1096348012451460

Loureiro, S. M. C. (2014). The role of the rural tourism experience economy in place attachment and behavioral intentions. International Journal of Hospitality Management, 40, 1-9. https://doi.org/10.1016/j.ijhm.2014.02.010

Magalog-De Veyra, J. (2018, April 28). Going to Sisig Fiesta? 7 restaurants for your Pampanga food trip. Retrieved June 23, 2019, from https://news.abscbn.com/life/04/28/18/going-to-sisig-fiesta-7-restaurants-for-your-pampangafood-trip

Mason, M. C., \& Paggiaro, A. (2012). Investigating the role of festivalscape in culinary tourism: The case of food and wine events. Tourism Management, 33(6), 1329-1336. https://doi.org/10.1016/j.tourman.2011.12.016

McKercher, B. F., Okumus, F., \& Okumus, B. (2008). Food tourism as a viable market segment: It's all how you cook the numbers! Journal of Travel and Tourism Marketing, 25(2), 137-148. https://doi.org/10.1080/10548400802402404

Mechinda, P., Serirat, S., \& Gulid, N. (2009). An examination of tourists' attitudinal and behavioral loyalty: Comparison between domestic and international tourists. $\begin{array}{llll}\text { Journal of Vacation } & \text { Marketing, } & \text { 15(2), }\end{array}$ https://doi.org/10.1177/1356766708100820

Meleddu, M., Paci, R., \& Pulina, M. (2015). Repeated behaviour and destination loyalty. Tourism Management, 50, 159-171. https://doi.org/10.1016/j.tourman.2015.01.032

Namkung, Y., \& Jang, S. (2007). Does food quality really matter in restaurants? Its impact on customer satisfaction and behavioral intentions. Journal of Hospitality $\mathcal{E}$ Tourism Research, 31(3), 387-409. https://doi.org/10.1177/1096348007299924

Ngwira, C., \& Kankhuni, Z. (2018). What attracts tourists to a destination? Is it attractions? African Journal of Hospitality, Tourism and Leisure, 7(1), 1-19.

Nikjoo, A. H., \& Ketabi, M. (2015). The role of push and pull factors in the way tourists choose their destination. Anatolia, 26(4), 588-597. https://doi.org/10.1080/13032917.2015.1041145

Nunnally, J. C. (1978). Psychometric theory. New York, NY: McGraw Hill.

Nunnally, J. C., \& Bernstein, I. H. (1994). Psychometric theory. New York, NY: McGraw Hill.

Oliver, R. L. (2014). Satisfaction: A behavioral perspective on the consumer: A behavioral perspective on the consumer. Routledge.

Pearl, J. (2009). Causality: Models, reasoning, and inference. Cambridge England: Cambridge University Press.

Prayag, G., \& Ryan, C. (2012). Antecedents of tourists' loyalty to Mauritius: The role and influence of destination image, place attachment, personal involvement, and satisfaction. Journal of Travel Research, 51(3), 342-356. https://doi.org/10.1177/0047287511410321 
Rodríguez, I., \& San Martín, H. (2008). Tourist satisfaction a cognitive-affective model. Annals of Tourism Research,35(2), 551-573. https://doi.org/10.1016/j.annals.2008.02.006

San Martín, H., Herrero, A., \& García de los Salmones, M. D. M. (2018). An integrative model of destination brand equity and tourist satisfaction. Current Issues in Tourism, 1-22. https://doi.org/10.1080/13683500.2018.1428286

Sherif, C., \& Sherif, M. (1967). Attitude, Ego-Involvement and Change. New York: John Wiley.

Sims, R. (2009). Food, place and authenticity: Local food and the sustainable tourism experience. Journal of Sustainable Tourism, 17(3), 321-336. https://doi.org/10.1080/09669580802359293

Smith, S., \& Costello, C. (2009). Culinary tourism: Satisfaction with a culinary event utilizing importance-performance grid analysis. Journal of Vacation Marketing, 15(2), 99-110. https://doi.org/10.1177/1356766708100818

Sparks, B. (2007). Planning a wine tourism vacation? Factors that help to predict tourist behavioural intentions. Tourism management, 28(5), 1180-1192. https://doi.org/10.1016/j.tourman.2006.11.003

Suhartanto, D., Clemes, M. D., \& Wibisono, N. (2018). How experiences with cultural attractions affect destination image and destination loyalty. Tourism Culture $\mathcal{E}$ Communication, 18(3), 176-188. https://doi.org/10.3727/109830418X15319363084463

Tenenhaus, M., Vinzi, V. E., Chatelin, Y. M., \& Lauro, C. (2005). PLS path modeling. Computational Statistics \& Data Analysis, 48(1), 159-205. https://doi.org/10.1016/j.csda.2004.03.005

Thomson, J. (2017, September 6). This is Sisig, the food Anthony Bourdain says will be the next big trend. Retrieved June 23, 2019, from https://www.huffpost.com/entry/what-is-sisig-anthonybourdain_n_59396d17e4b0b13f2c68002e

Tsai, C. T. (2016). Memorable tourist experiences and place attachment when consuming local food. International Journal of Tourism Research, 18(6), 536-548. https://doi.org/10.1002/jtr.2070

Wagner, C. H. (1982). Simpson's paradox in real life. The American Statistician, 36(1), 46-48. https://doi.org/10.1080/00031305.1982.10482778

Wetzels, M., Odekerken-Schröder, G., \& Van Oppen, C. (2009). Using PLS path modeling for assessing hierarchical construct models: Guidelines and empirical illustration. MIS quarterly, 33(1), 177-195. https://doi.org/10.2307/20650284

Žabkar, V., Brenčič, M. M., \& Dmitrović, T. (2010). Modelling perceived quality, visitor satisfaction and behavioural intentions at the destination level. Tourism Management, 31(4), 537-546. https://doi.org/10.1016/j.tourman.2009.06.005

Zaichkowsky, J. L. (1985). Measuring the involvement construct. Journal of Consumer Research, 12, 341-352. https://doi.org/10.1086/208520 